\title{
Simone de Beauvoir som opdagelse \\ og som pensum
}

ESSAY

\section{Af Mette Kunøe og}

KIRSTEN GOMARD

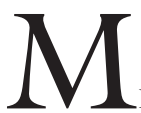

ETTE KunøE

(født 1937): Jeg læste Simone de Beauvoir i 1970, og det kom sig sådan: En skønne dag i november 1970 så jeg et opslag på universitetet. Det var håndlavet, en collage af udklip fra dameblade med billeder fortrinsvis af brystholdere og roll-ons - en slags elastiske hofteholdere, som det var en pine at gå med. Med lidt besvær kunne jeg mellem sammenklæbningerne læse, at nogen ville have de kvindelige læsere af opslaget til at komme til et møde på Aarhus Seminarium den 16.11.1970. (I parentes bemærket kan jeg fortælle, at Aarhus Seminarium dengang blev ledet af en indremissionsk bestyrelse, og ifølge Anne Marie Fjord Jensen, som var ansat på seminariet, syntes rektor på den ene side, det var så pinligt at have brystholderplakaterne hængende fremme den dag, der skulle være bestyrelsesmøde, at han egenhændigt tog dem ned - men han var på den anden side tolerant nok til at sætte dem op igen, da bestyrelsen var gået).

Med spilvågen nysgerrighed gik jeg derhen og så for første gang en stor gruppe kvinder, der skulle blive absolut afgørende for de næste år af mit liv. Det var det første 
rødstrømpemøde i Århus, skønt vi ikke vidste det og slet ikke brugte navnet Rødstrømper endnu.

Der stod nogle fyre sammen med os ved indgangen og ville ind. Sanne Lyhne har fortalt mig, at en af dem råbte: "Kxllingerne skal ikke politisere uden mænd!". En anden styrtede ind, da porten blev lukket op. Han ville med til mødet. Han mente simpelthen, det var ulovligt, at kvinder holdt møder uden mænd. Han fik besked på, at han skulle forlade mødet omgående. I stedet kastede han sig op på flygellåget og klamrede sig fast til kanten med knoer, der var hvide af anstrengelse. Han ville ikke gå. Jeg var med til at trække ham i benene det hjalp ikke. Men lidt senere luskede han dog ned af flyglet og gik sin vej. Senere har jeg erfaret fra Britta Skovgaard, at mens vi holdt møde, sad en gruppe fyre i baren under stakladen og snakkede om os. En ledende studenteraktivist, lad os bare kalde ham Noffe, udtalte de udødelige ord: "Dér sidder flere hundrede af byens bedste fisser ovre på Århus Seminarium, og vi må ikke komme ind!".

Vi på mødet påhørte først nogle københavnske rødstrømper, og efter en del snak og debat blev vi enige om at inddele os $\mathrm{i}$ basisgrupper. Det skete efter et lidt tilfældigt princip. Men lidt efter sad jeg med seks andre kvinder, som jeg ikke kendte i forvejen, og udvekslede navne og adresser. Netop dét øjeblik står plastisk og farverigt i huskommelsen. Jeg vil til enhver tid kunne udpege det sted i rummet, hvor vi sad og bøjede hovederne ind mod hinanden og skrev på papirslapperne.

Vi skulle mødes hos en læge i gruppen et par dage efter. Hun var selv gift med en læge, og han var meget jaloux over, at vi skulle holde møde, og at han ikke måtte være med. Derfor greb han til en del stærke gloser, der straks blev opfanget og gentaget af familiens store grønne papegøje. Symbolikken i dét gik ikke upåagtet hen!

Vi blev enige om først at tage en præsentationsrunde og fortælle lidt om os selv, og- så noget helt nyt for os. Jeg kan tydeligt huske, at jeg var meget ubehagelig til mode ved at gøre det. Min verden var universitetets, og dér var det simpelthen det værste af alt at tale privat $\mathrm{i}$ forsamlinger. $\mathrm{Og}$ så var jeg enlig mor til en dengang 3-årig pige, men havde ikke lyst til at fortælle om min store kærlighed, som havde forladt mig og barnet. Men hvis jeg ikke skulle fortælle om dét, hvordan kunne jeg så gerere mig? Jeg undveg problemet ved at fortælle tørre facts fra mit CV.

Næste punkt var, hvad vi skulle starte med i basisgruppen. Og selvfølgelig greb vi til det, vi kendte bedst: Vi skal læse en bog og diskutere den! Og hvad skal det være for en bog? Flere havde hørt om Simone de Beauvoir og hendes bog Le deuxieme sexe. Jeg hittede ud af, at den fandtes på engelsk i en billigbogsudgave til under $10 \mathrm{kr}$. Og det betød, at vi gik i gang med The Second Sexl i Bantam Paperback-udgaven, der er "complete and unabridged", som der står på forsiden. Dengang som nu lige overraskende er forsidebilledet et gyldent fotografi af en ung, slank, smuk, nøgen kvinde, der lader sig beskue siddende på knæ i profil i fodenden af en seng; hun bøjer sig fremover, så barmen fremtræder fordelagtigt, og ser ned på en buket utydelige blomster. Noget for husarerne? Forsideteksten under titlen tyder på det. Den siger i hvert fald "The subject is Woman - and the treatment is fascinating. One of the few great books of our era. The Saturday Review". Udgaven er på 705 sider, og vi læste ca. 100 sider til hvert af de ugentlige møder.

Hvordan gik læsningen af Simone de Beauvoir? Ja, teksten er faktisk uhyre vanskelig at forstå i denne udgave. Den er fyldt med sjældne og sære ord, og den lider under at være oversat alt for tæe på den franske original. Så jeg famlede mig igennem. Blev glad, når jeg forstod et afsnit eller en pointe, og blev chokeret over hendes ligefremhed: "It is certainly true that woman's sex pleasure is quite different from man's" (371). 
Der er sætninger, jeg har understreget: "Thus the ideal of the average Western man is a woman who freely accepts his domination, who does not accept his ideas without discussion, but who yields to his arguments, who resists him intelligently and ends by being convinced. The greater his pride, the more dangerous he likes his adventures to be: it is much more splendid to conquer Penthesilea than to marry a yielding Cinderella" (172). Eller: "Men do not like garcons manques, or bluestockings, or brainy women" (314). Jamen, det var som talt ud af min mund. Jeg var faktisk i skolen og i studierne dygtigere end drengene. Men det var meget usexy at være dét. Så man gjorde sig med flid sødt smilende dummere, løj sine karakterer lavere, gav efter til slut i diskussioner, mens man slog et par gange med øjenvipperne og så beundrende på fyren.

Der er også masser af understregninger i moder-afsnittene, for dér var fantastiske afsløringer, som man havde tænkt i det dunkle, men aldrig formuleret: "the adolescent girl is not given the encouragement accorded to her brothers - quite the contrary. She is expected to be also a woman. (...) The mother is secretly hostile to her daughter s liberation, (...) but the boys effort to become a man is respected" (312). Uh, hvor jeg kendte det. Min mor har stædigt i alle årene holdt på, at kvinder ikke duer som præster, læger, tandlæger etc., og at hun i hvert fald aldrig ville benytte sådan en.

"Careless gaiety is in itself bad deportment; the self-control that is imposed on women and becomes second nature in "the well-bred young girl" kills spontaneity; her lively exuberance is beaten down. The result is tension and ennui". Her mindedes jeg alle de læresætninger i mit hjem og i skolen, der blev gentaget til hudløshed: “ikke være næsvis!", “være artig, ikke være uartig!", "være en flink pige!", "ikke være næsvis!”, “være velopdragen, ikke være uopdragen!”, “sidde stille og lege lam!”, “ikke være næsvis!”, “ses, men ikke høres!”, “ikke svare igen!”, “ikke være næsvis!”. Og hvis vi ikke var flinke, så var der lussingerne, som hang løst i skole og hjem, helt op til vi var 15-16 år.

Kort sagt: Vi brugte Simone de Beauvoir helt bogstaveligt til at forstå os selv. Til at få ord på det, vi fornemmede. Til at lære en masse om kvindekønnet. Vi var i vores opvækst blevet deformeret som en kinakvindes fod til at se på verden, litteraturen, os selv, med mænds øjne, til at finde dét interessant, som de definerede som interessant. Det var tydeligt, at de ikke syntes, vort køn var interessant i sig selv, kun som spejling af dem. Og her var vi igang med, via denne bog, at opdage kvindekønnet som et nyt, enormt interessant og for os eksistentielt emne.

Vi i basisgruppen snakkede til højre og venstre om bogen. Men ingen andre basisgrupper bandt an med den. Vi var og blev alene om oplevelsen.

Jeg selv holdt fast i opdagelsen og oplevelsen og i Simone, og jeg har i årene derefter læst hele hendes forfatterskab. Bedst har jeg syntes om En velopdragen ung piges erindringer, som jeg læste i 1987. Dér var for mig noget af suset igen fra den første læsning i basisgruppen af The Second Sex.

\section{K} andet $k ø n$ hører ikke til min ungdoms læseoplevelser. Jeg har først læst den langt senere, omkring 1990, da jeg allerede længe havde været involveret $\mathrm{i}$ kvinde- og kønsforskning. Som underviser i det kursusforløb, der på Cekvina hedder "Teorier og Metoder i Kvinde- og Kønsforskning”, måtte jeg jo nødvendigvis også kende til Simone de Beauvoir. Jeg har altså læst bogen på et tidspunkt, da jeg forlængst var feministisk engageret og var ret velbevandret i (andre) teorier om køn, og jeg har det blandet med den: Den er et pionerarbejde, 
og jeg gik til den med den respekt, en sådan klassiker fortjener. Jeg var virkelig nysgerrig og blev lidt skuffet.

For mig var den erkendelse, at kvinder er "det andet køn" ikke længere nogen ahaoplevelse. Jeg var (og er) bestemt ikke uenig, men den store gamle dames synspunkter var i høj grad blevet indoptaget og bearbejdet i anden feministisk litteratur, som jeg havde læst, og efter de første 100 sider var jeg temmelig træt af bogen. Den er knirkende og tør og gentager sin pointe $\mathrm{i}$ én uendelighed under inddragelse af mere og mere litteratur, men jeg læste dog høfligt og nogenlunde tålmodigt videre. Min oplevelse var, at det efterhånden måske mindre drejede sig om at illustrere pointen og i højere grad at bevise for alverden, ikke mindst mændene, at Simone de Beauvoir var værdig til transcendensen $\mathrm{i}$ deres selskab.

Måske hænger det også sammen med, at min egen forståelse af kvindefrigørelse ikke har så meget med transcendens i eksistentialistisk forstand at gøre. Jeg fandt nedvur- deringen af kvinders praktiske gøremål og af moderskabet rent ud sagt uforskammet og opvurderingen af mændenes engagementer og aktiviteter ensidig. Min vision var dengang såvel som nu, at både kvinder og mænd skal kunne forene forældreskab og praktiske gøremål i familien med den side af tilværelsen, Simone betegner som det transcendente, så dér stod jeg af.

Men: historisk set er det en vigtig bog, der bestemt fortjener opmærksomhed her ved 50-års-jubilæet. Når det gælder feminismens klassikere, hører den til pensum.

\section{Note}

1. Beauvoir, Simone de: The Second Sex, Bantam, New York 1966.

Mette Kunøe, cand.mag., afdelingsleder, Aarhus Universitet

Kirsten Gomard, cand.mag., lektor, Aarhus Universitet 